\title{
Growth performance of goldfish, Carassius auratus and basil, Ocimum basilicum in media bed aquaponics
}

\author{
P. A. PATIL ${ }^{1}$, K. DUBE ${ }^{2}$, A. K. VERMA ${ }^{2}$, N. K. CHADHA ${ }^{2}$, J. K. SUNDARAY ${ }^{3}$ AND \\ P. JAYASANKAR ${ }^{4}$ \\ ${ }^{1}$ ICAR-Central Institute of Brackishwater Aquaculture, Chennai - 600 028, Tamil Nadu, India \\ ${ }^{2}$ ICAR-Central Institute of Fisheries Education, Mumbai - 400 061, Maharashtra, India \\ ${ }^{3}$ ICAR-Central Institute of Freshwater Aquaculture, Bhubaneswar - 751 002, Odisha, India \\ ${ }^{4}$ ICAR-Central Marine Fisheries Research Institute, Kochi - 682 018, Kerala, India \\ e-mail: patilpankaj@ciba.res.in,pankaj090178@gmail.com
}

\begin{abstract}
An experiment of 36 days duration was conducted to study growth performance of goldfish Carassius auratus and basil Ocimum basilicum reared in a media bed aquaponic system. Goldfish fry $(3.32 \pm 0.45 \mathrm{~g}$ and $4.20 \pm 0.39 \mathrm{~cm})$ were stocked in rectangular 751 capacity (water volume of 50 l) plastic tanks at three different stocking densities viz., $500 \mathrm{~m}^{-3}(\mathrm{~T} 1), 600 \mathrm{~m}^{-3}(\mathrm{~T} 2)$ and $700 \mathrm{~m}^{-3}$ (T3), respectively and basil plants were planted at a density of $20 \mathrm{~m}^{-2}$, i.e., 10 plants $0.44 \mathrm{~m}^{-2}$ in the rectangular plastic tanks filled with crushed stone media. The goldfish fry were fed with artificial feed (33\% protein) at $5 \%$ of body weight in equal proportions, two times a day. Control (C) group was set with only basil plants. Growth parameters of goldfish such as length gain (\%), weight gain (\%) and specific growth rate $\left(\% \mathrm{~d}^{-1}\right)$ were significantly higher in $\mathrm{T} 3(\mathrm{p}<0.05)$ as compared to T1 and T2. However, feed conversion ratio (FCR) and protein efficiency ratio (PER) did not differ between treatments. Similarly, basil plant growth in terms of height gain (\%) and leaves yield (nos. plant ${ }^{-1}$ ) were found to be highest in T3 which was significantly different from T1, T2 and control (C). Throughout the experimental period, values of water parameters in all the treatments were found to be in favourable ranges. From the results of the present study, it could be concluded that for maintaining good water quality with highest production in media bed aquaponics, the optimum stocking density is $700 \mathrm{~m}^{-3}$ for goldfish fry and 10 plants per $0.44 \mathrm{~m}^{2}$ for basil plants.
\end{abstract}

Keywords: Aquaponics, Basil, Goldfish, Media bed system, RAS

Considering the scarcity of water and land resources, development of new and sustainable culture systems is required to meet the future demands of food and income (Fedoroff et al., 2010). Also, presently most of the freshwater resources are utilised for various agricultural activities and in this scenario to increase the income and to alleviate rural poverty, there is a need for sustainable technology through reuse of water in semi-intensive or intensive production systems (Ahmad et al., 2016, 2017; Harsh et al., 2017). Hence, intensification of fish farming by maximum utilisation of water and nutrient resources and minimising environmental impacts will result in further expansion of aquaculture (Hu et al., 2015).

The recirculating aquaculture system (RAS) is an intensive system for culture of fish which use lesser amount of water than conventional farming and the higher water nutrient concentration can be used for vegetable production through aquaponics. Aquaponics is a symbiotic combination of two established systems i.e. RAS and hydroponics. In this system, water recirculation reduces the water use by transferring nutrients from aquaculture to hydroponics and nutrient recycling in hydroponics (Turcios and Papenbrock, 2014).

The value of ornamental fish trade has grown significantly over the past decades. Between 2000 and 2011, global exports of ornamental fish increased from US\$181 million to US\$372 million (FAO, 2014a). Though the ornamental fish market's contribution to the world trade in terms of value is small; overall, the sector plays a prominent role in terms of developing hobbies, offering services, job opportunities to new professionals, poverty alleviation and contributing to the economic growth in developing countries. At present, aquaculture mainly focuses on food fish production but ornamental fish production is also an important component in several Asian countries. Thus, in the upcoming years, ornamental fish culture and production in aquaponic system has huge potential for higher producion and income with less requirement of land, water, labour and other inputs.

As compared to food fishes, a few ornamental fish species have been used in aquaponic systems which 
mostly include Carassius auratus, Cyprinus carpio var. koi (Shete et al., 2013a, b; Hussain et al., 2015; Nuwansi et al., 2016; Nuwansi et al., 2017; Shete et al., 2017). Among these, goldfish C. auratus (Linnaeus 1758) of the Cyprinidae family remained popular due to their hardy nature which makes it an excellent aquarium species as well as laboratory species. Intensification of goldfish production is needed to meet the growing demand of the ornamental fish market and hobbyists. Goldfish excretes a large amount of wastes which results in the increased water requirement for its culture and it also cause increased discharge of nutrients to the environment resulting in pollution.

Nowadays in most of the scientific research work as well as in domestic and commercial aquaponics units, more than 150 different varieties of flowers, herbs, vegetables and small trees have been demonstrated, cultured and grown successfully (FAO, 2014b). Lettuce, herbs, onion, cabbage, cauliflower, garlic, peas and specially green vegetables (spinach, chives and basil) are well adapted to aquaponic system and have low to medium nutritional requirement; whereas, fruiting plants like tomatoes and cucumbers with higher nutritional demand, perform better only in heavily stocked and well established aquaponic systems (Rakocy, 1997). Among the green vegetables, basil plant is mostly grown in large-scale commercial monoculture aquaponics units due to its high nutritional value and high demand in urban or peri-urban areas. It is an ideal plant for aquaponics due to its higher nitrogen uptake capacity and within about 5-6 weeks it grows to harvesting size of $15 \mathrm{~cm}$ (FAO, 2014b). For culture of high-value ornamental fishes or high yield specialty crops like medicinal herbs, the media bed aquaponic systems are usually most suitable. Shete et al. (2015) reported that a ratio of 1:2 (fish:plant) is optimum for carp fish production, mint plant growth as well as nutrient removal.

Culture of ornamental fishes in aquaponic systems is an emerging hobby in India. Ornamental fish culture in the aquaponic system has a good potential to be an alternative source of income to the farmers. Thus, for the efficient recycling of water and future sustainability of aquaculture, there is a need for establishing optimised technology for cost-effective farming of ornamental fishes in aquaponics systems for the hobbyists, researchers as well as farmers. Hence, this study was conducted to assess the growth performance as well as to optimise the stocking density of goldfish and basil in media bed aquaponics.

The study was conducted for a period of 36 days at the Aquaponics unit of Division of Aquaculture, ICAR-Central Institute of Fisheries Education (ICARCIFE), Mumbai. Fry of goldfish (C. auratus) were obtained from commercial ornamental fish breeders in Mumbai and disinfected by giving immersion treatment with $5 \mathrm{ppm} \mathrm{KMnO}_{4}$. Prior to initiation of the experiment, the fishes were acclimatised for one week at the experimental site. Basil seeds were procured from the Ratanshi AgroHortitech, Byculla, Mumbai. Seeds were sown in the open land of aquaponics unit and allowed to grow (4-6 cm) for 15 days before transplanting into the experimental setup.

For the media bed aquaponic system setup, rectangular tanks of 751 (water volume 50 1) capacity were selected for fishes and 1001 capacity (plant grow bed $0.80 \times 0.55 \mathrm{~m}$ ) were used for basil plant growout (hydroponics). The whole system was set up on two-tier aquarium stands in such way that fish tanks were fitted in the bottom tier of the stand while hydroponics tanks were above the fish tank in the upper tier in order to facilitate gravitational flow of water from the hydroponics tank to fish tank. The hydroponics tanks were filled with washed and cleaned gravel to maintain a gravel bed $(15 \mathrm{~cm})$ for plants. Five days prior to stocking, all fish tanks were disinfected, cleaned and air dried. To maintain the flood and drain system in each plant growout tank, a bell siphon system fabricated with PVC pipe was connected to fish tank and water from hydroponics tanks was recirculated (gravitationally) to fish tank through the small groove at the bottom of the tank. Also, to control the water flow from water pumps, a cyclic timer (Crouzet TMR 48 1) was set to switch on the pumps for $5 \mathrm{~min}$ and off for $10 \mathrm{~min}$ in every cycle. After making all the connections and setting up the system, borewell water was filled into the experimental tanks (50 1) and recirculated from fish tank to hydroponics tank through PVC pipe (0.5") with the help of submersible water pump (TK-380, $1.5 \mathrm{~m}$ height, $15 \mathrm{~W}$ ). The system was put on dry run for 5 days prior to start of the experiment. Around 81 water was pumped and 7-7.5 1 water was drained in each cycle.

Gold fish fry were stocked at three different stocking densities of $500 \mathrm{~m}^{-3}$ (T1), $600 \mathrm{~m}^{-3}$ (T2) and $700 \mathrm{~m}^{-3}$ (T3). Control (C) comprised on basil plants in plant growout tanks and no fish in the fish culture tanks. For the experiment, completely randomised design (CRD) was followed using three replicates for each treatment and control. Fry of goldfish (3.5-5 cm and 2.5-4.3 g) were stocked in each tank according to assigned stocking density with a mean stocking size of $4.20 \pm 0.39 \mathrm{~cm}$ and $3.32 \pm 0.45$ g. Basil plants were transplanted from to the experimental tanks at a stocking density of 10 plants per tank (plant bed area $0.44 \mathrm{~m}^{2}$ ) in each treatment and control. The average stocking size of plants was $4.20 \pm 0.39 \mathrm{~cm}$. Goldfish fry were fed with artificial feed (33\% protein) at $5 \%$ body weight in two equal meals a day (at 10:30 and 16:30 hrs). 
For evaluation of growth parameters, goldfish and basil plants were sampled at 6 days intervals. Growth parameters of fish viz., length $(\mathrm{cm})$, weight $(\mathrm{g})$, length gain $(\%)$, weight gain $(\%)$, specific growth rate (SGR), feed conversion ratio (FCR) and protein efficiency ratio (PER) were analysed. Different water quality parameters viz., temperature, $\mathrm{pH}$, dissolved oxygen (DO), free carbon dioxide $\left(\mathrm{CO}_{2}\right)$, total hardness, total alkalinity, ammonia, nitrite and nitrate were recorded throughout the study at 6 days intervals, following standard methods (APHA, 2005). Basil plant growth was estimated by measuring the height of plants $(\mathrm{cm})$ with the help of a graduated ruler. On termination of the experiment, the leaves of basil plants were harvested and counted individually to determine the yield of harvested leaves.

Data were analysed using statistical package SPSS version 16 in which one way ANOVA and Duncan's Multiple Range test were performed at a significance level of $\mathrm{p}<0.05$.

In the present study, the mean values and weekly variation in average values of water temperature $\left({ }^{\circ} \mathrm{C}\right), \mathrm{pH}$, dissolved oxygen $\left(\mathrm{mg} \mathrm{l}^{-1}\right)$, free carbon dioxide $\left(\mathrm{mg} \mathrm{l}^{-1}\right)$, total alkalinity $\left(\mathrm{mg} \mathrm{l}^{-1}\right)$, total hardness $\left(\mathrm{mg} \mathrm{l}^{-1}\right)$, ammonianitrogen (TAN) (mg l-1), nitrite-nitrogen (Nitrite-N) $\left(\mathrm{mg} \mathrm{l}^{-1}\right)$, nitrate-nitrogen (Nitrate-N) $\left(\mathrm{mg} \mathrm{l}^{-1}\right)$ and phosphate concentrations $\left(\mathrm{mg} \mathrm{l}^{-1}\right)$ observed during the experimental period are given in Table 1 and depicted in Figs. 1-10, respectively. The temperature and $\mathrm{pH}$ values were more or less similar in control and treatments. Similarly, not much variation was observed in the values of total alkalinity and total hardness over the experimental period.

The maintenance of DO to an optimum level is very important for fish health and growth. For optimum growth of warm water fishes, the DO levels should be maintained above $5 \mathrm{mg} \mathrm{l}^{-1}$ (Masser et al., 1999). The level of DO throughout the experimental duration varied between 5.6 and $7.2 \mathrm{mg} \mathrm{l}^{-1}$. The mean values of DO levels in the water were found to be higher in the control group followed by T1, T2 and the lowest in T3. However, no significant difference was observed in the mean values of DO levels of T1, T2 and T3 and found within favourable range required for goldfish culture. According to Boyd and Lichtkoppler (1979) fish avoid free $\mathrm{CO}_{2}$ levels as low as $5 \mathrm{mg} \mathrm{l}^{-1}$ but most species can survive in waters containing up to $60 \mathrm{mg} \mathrm{l}^{-1} \mathrm{CO}_{2}$, provided DO concentrations are high. The concentration of free $\mathrm{CO}_{2}$ during the experimental period varied between 0.67 and $4.67 \mathrm{mg} \mathrm{l}^{-1}$. The mean values of free $\mathrm{CO}_{2}$ were higher in T3 followed by T2, T1 and lowest in the control group. Further, mean values of the free $\mathrm{CO}_{2}$ content in $\mathrm{T} 1, \mathrm{~T} 2$ and T3 were statistically similar but found significantly higher than control.

The levels of TAN, nitrite-N and nitrate- $\mathrm{N}$ concentration during the experimental period varied between 0.025 and $0.275 \mathrm{mg} \mathrm{l}^{-1}, 0.01$ to $0.12 \mathrm{mg} \mathrm{l}^{-1}$ and 0.08 to $0.4 \mathrm{mg} \mathrm{l}^{-1}$, respectively. However, at the end of experiment, the mean concentrations of TAN in the water was found to be higher in T3 followed by T2, T1 and lowest in control group. The mean values of TAN concentrations in treatments $\mathrm{T} 1, \mathrm{~T} 2$ and $\mathrm{T} 3$ showed no significant difference but found significantly higher than the control. The results revealed the effectiveness of the media-bed aquaponic system in maintaining the optimum level of TAN for culturing fish and plants without any water exchange. Similar trend was also observed in the mean values of nitrite- $\mathrm{N}$ and nitrate- $\mathrm{N}$ concentrations among the treatments and control. For fish growth, ammonia and nitrite-N are toxic but nitrate is comparatively harmless and for growing higher plants, nitrate is the most preferred form of nitrogen (Rakocy et al., 2006). During the entire study period, nitrite-N and nitrate-N concentrations did not vary significantly among different treatment groups and found to be in acceptable limits.

Table 1 . Water quality parameters recorded during the experiment (Mean $\pm \mathrm{SE}$ )

\begin{tabular}{|c|c|c|c|c|}
\hline \multirow{2}{*}{ Parameters } & \multicolumn{4}{|c|}{ Treatments } \\
\hline & $\mathrm{C}$ & $\mathrm{T} 1$ & $\mathrm{~T} 2$ & $\mathrm{~T} 3$ \\
\hline Temperature $\left({ }^{\circ} \mathrm{C}\right)$ & $27.15 \pm 0.23^{\mathrm{a}}$ & $27.11 \pm 0.24^{\mathrm{a}}$ & $26.97 \pm 0.24^{\mathrm{a}}$ & $27.01 \pm 0.62^{\mathrm{a}}$ \\
\hline $\mathrm{pH}$ & $7.19 \pm 0.23^{\mathrm{a}}$ & $7.16 \pm 0.23^{\mathrm{a}}$ & $7.26 \pm 0.23^{\mathrm{a}}$ & $7.26 \pm 0.64^{\mathrm{a}}$ \\
\hline $\mathrm{DO}\left(\mathrm{mg} \mathrm{l}^{-1}\right)$ & $6.94 \pm 0.37^{\mathrm{a}}$ & $6.62 \pm 0.50^{\mathrm{b}}$ & $6.55 \pm 0.62^{\mathrm{b}}$ & $6.48 \pm 0.43^{\mathrm{b}}$ \\
\hline Free $\mathrm{CO}_{2}\left(\mathrm{mg} \mathrm{l}^{-1}\right)$ & $0.50 \pm 0.20^{\mathrm{a}}$ & $2.03 \pm 0.17^{b}$ & $2.60 \pm 0.28^{\mathrm{b}}$ & $2.70 \pm 0.21^{\mathrm{b}}$ \\
\hline Hardness $\left(\mathrm{mg} \mathrm{l}^{-1}\right)$ & $72.24 \pm 0.28^{\mathrm{a}}$ & $72.47 \pm 0.26^{\mathrm{a}}$ & $71.43 \pm 1.02^{\mathrm{a}}$ & $73.33 \pm 1.15^{\mathrm{a}}$ \\
\hline Alkalinity $\left(\mathrm{mg} \mathrm{l}^{-1}\right)$ & $77.62 \pm 1.62^{\mathrm{a}}$ & $77.33 \pm 1.83^{\mathrm{a}}$ & $76.09 \pm 1.19^{\mathrm{a}}$ & $76.19 \pm 1.15^{\mathrm{a}}$ \\
\hline TAN $\left(\mathrm{mg} \mathrm{l}^{-1}\right)$ & $0.11 \pm 0.01^{\mathrm{a}}$ & $0.12 \pm 0.45^{\mathrm{b}}$ & $0.13 \pm 0.47^{\mathrm{b}}$ & $0.15 \pm 0.20^{\mathrm{b}}$ \\
\hline Nitrite $\left(\mathrm{mg} \mathrm{l}^{-1}\right)$ & $0.005 \pm 0.001^{\mathrm{a}}$ & $0.012 \pm 0.01^{\mathrm{b}}$ & $0.012 \pm 0.01^{\mathrm{b}}$ & $0.014 \pm 0.01^{\mathrm{b}}$ \\
\hline Nitrate $\left(\mathrm{mg} \mathrm{l}^{-1}\right)$ & $0.01 \pm 0.03^{\mathrm{a}}$ & $0.22 \pm 0.05^{\mathrm{b}}$ & $0.23 \pm 0.06^{\mathrm{b}}$ & $0.23 \pm 0.02^{\mathrm{b}}$ \\
\hline Phosphate $\left(\mathrm{mg} \mathrm{l}^{-1}\right)$ & $0.29 \pm 0.42^{\mathrm{a}}$ & $0.77 \pm 0.15^{\mathrm{c}}$ & $0.75 \pm 0.15^{\mathrm{c}}$ & $0.70 \pm 0.20^{\mathrm{b}}$ \\
\hline
\end{tabular}

Values bearing same superscripts do not differ significantly $(\mathrm{p}>0.05)$ 


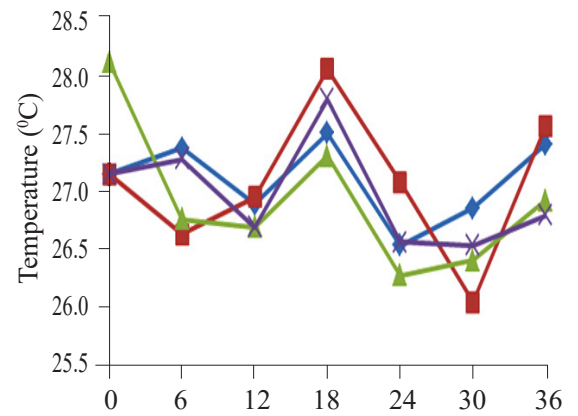

(a)

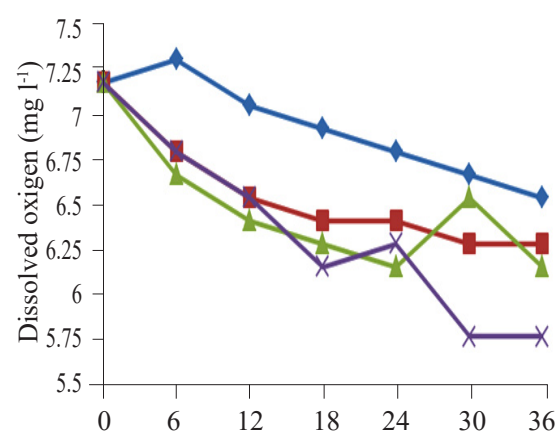

(d)

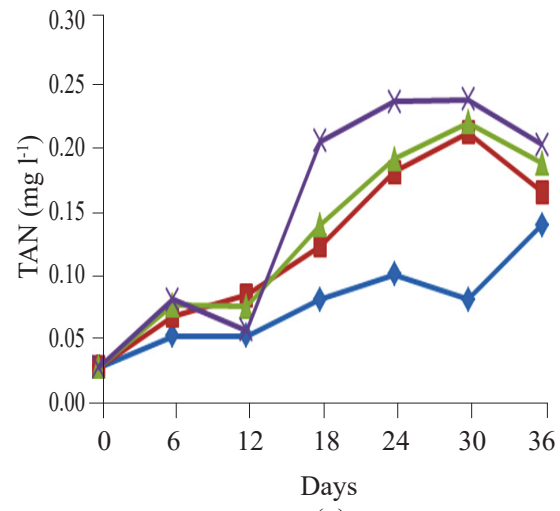

(g)

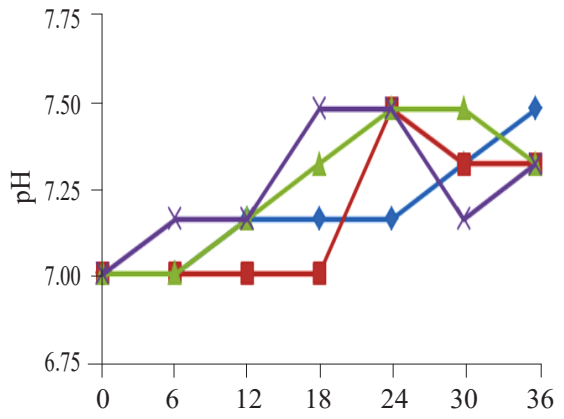

(b)

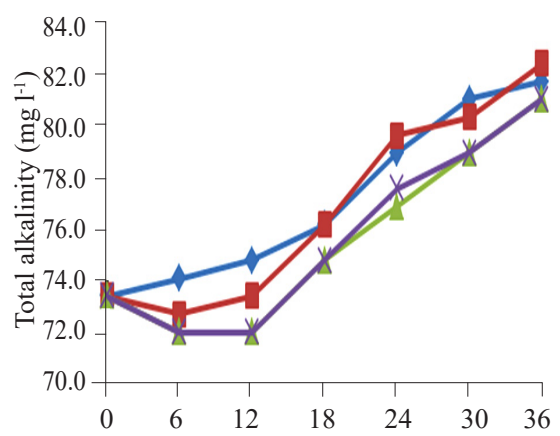

(e)

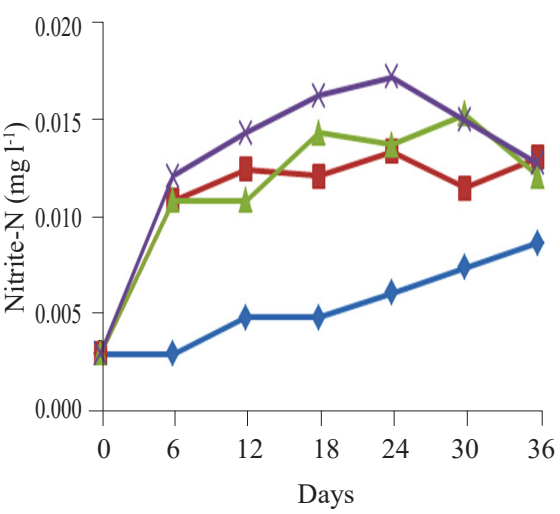

(h)

(j)

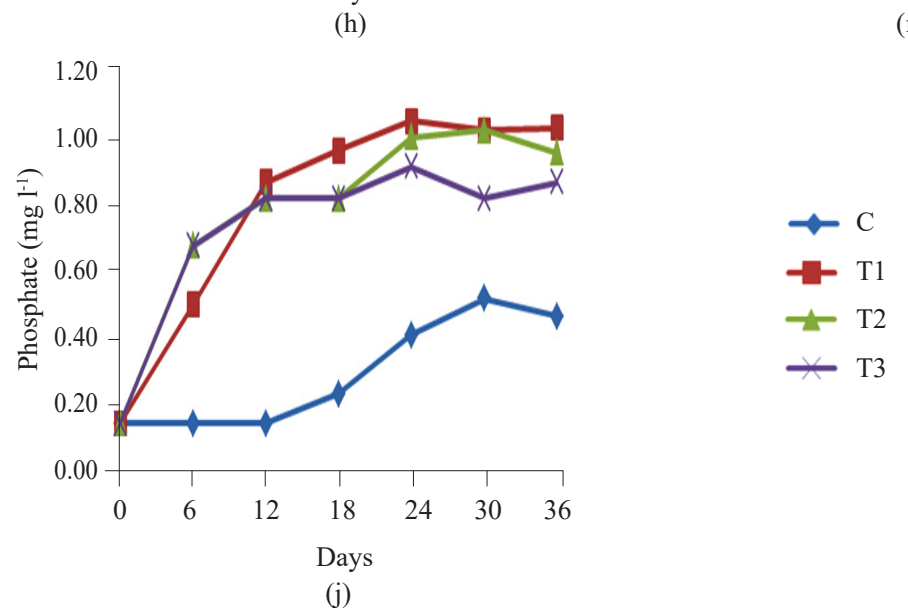

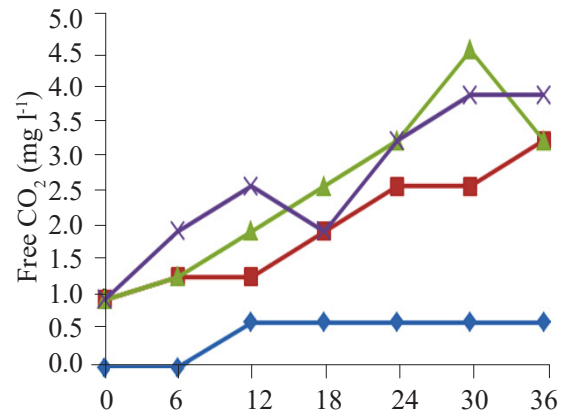

(c)

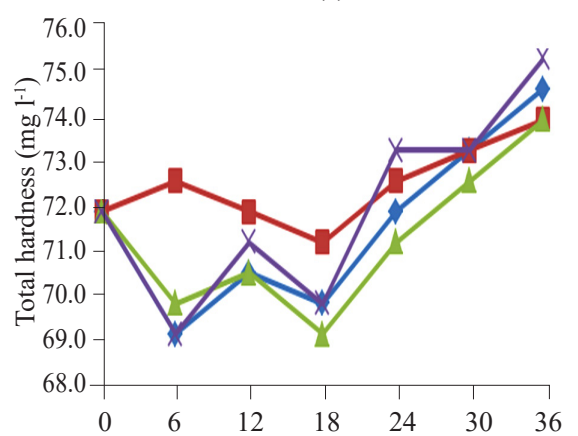

(f)

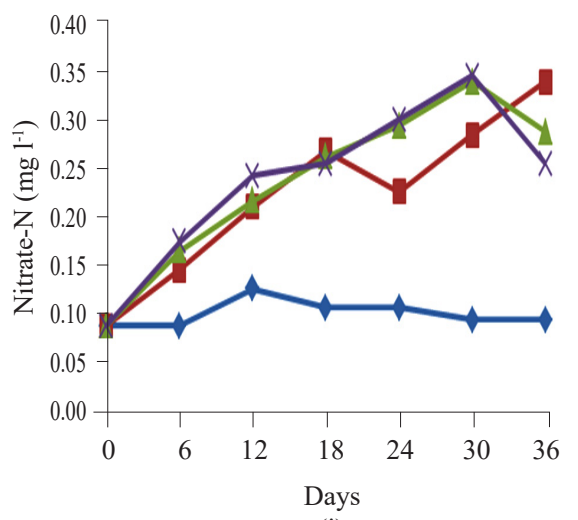

(i)

Fig. 1. Variations in (a) Temperature $\left({ }^{\circ} \mathrm{C}\right),\left(\right.$ b) $\mathrm{pH}$, (c) Free $\mathrm{CO}_{2}$, (d) DO, (e) Total alkalinity, (f) Total hardness, (g) TAN, (h) Nitrite-N, (i) Nitrate-N and (j) Phosphate in different treatments over a period of 36 days 
The phosphate concentrations varied from 0.14 to 1.04 $\mathrm{mg} \mathrm{l}^{-1}$ during the culture period. Mean values of phosphate concentration of water between control and treatment varied significantly throughout the culture period. The lowest concentration was recorded in control followed by T3, T2 and T1 respectively. Further, mean values of phosphate concentration in T1 and T2 were statistically similar. According to Jha and Barat (2005), higher stocking density of fishes causes high accumulation of excrements and metabolic wastes leading to accumulation of significantly higher concentration of nitrogen compounds in fish tanks. Thus, it can be concluded that the media bed aquaponic system maintains suitable water quality required for fish growth in tank culture systems without any daily water exchange.

The aquaponic system improves the income from the culture operation as it cuts down the cost of production to some level by the production of the secondary crop of vegetables from the same culture system. Depletion of DO and accumulation of organic matter, inorganic nitrogen, particularly ammonia and $\mathrm{CO}_{2}$ are the most common water quality problems encountered in recirculating aquaculture systems (Rijn, 1995), which can be reduced only through water replacement (Hamlin, 2006). The culture of plants in media bed aquaponics system, aids in absorption of nutrients from the culture water which eliminates the need for costly biofilters (Rakocy et al., 2006).

Effect of different fish densities was observed on fish growth (length and weight). Fish growth in terms of body weight $(\mathrm{g})$, length $(\mathrm{cm})$, weight gain $(\%)$ and length gain $(\%)$ of the goldfish varied significantly $(\mathrm{p}<0.05)$ between treatments (Table 2). At the end of the experimental duration, the highest fish growth was observed in the highest density as compared to other treatment groups. The mean body weight $(\mathrm{g})$, length $(\mathrm{cm})$, weight gain $(\%)$ and length gain $(\%)$ of the goldfish were found significantly $(\mathrm{p}<0.05)$ higher in T3 than T2 and T1. The present results indicated a mean survival of 98.23-98.67\% in all treatments (Table 2). Also, among the treatments, no significant difference was observed in mean survival (\%). Specific growth rate $\left(\% \mathrm{~d}^{-1}\right)$ followed the similar trend as that of growth showing the highest value in T3 followed by $\mathrm{T} 2$ and lowest value in T1. Specific growth rate $\left(\% \mathrm{~d}^{-1}\right)$ in $\mathrm{T} 1$ was significantly $(\mathrm{p}<0.05)$ higher than $\mathrm{T} 2$ and T3. Feed conversion ratio (FCR), feed efficiency ratio (FER) and protein efficiency ratio (PER) were found in the narrow range of 1.190-1.196, 0.833-0.843 and 1.50-1.56, respectively among treatments and were not significantly different $(\mathrm{p}>0.05)$.

Zarski et al. (2010) revealed that the semi-closed recirculating aquaculture system with $20 \%$ daily water replacement exhibited improved water quality parameters and better fish production during intensive culture of goldfish at a density of $500 \mathrm{~m}^{-3}$ in the closed and semiclosed recirculating system. Shete et al. (2013a) reported water circulation of $12 \mathrm{~h} \mathrm{~d}^{-1}$ for goldfish culture at stocking density of $500 \mathrm{~m}^{-3}$ is economical for goldfish and plant production in the aquaponic system.

The highest growth of fish as well as of plant observed at highest density during the present study, could be attributed to the better efficiency of plants to utilise the fish waste accumulated in the system resulting in maintaining optimum water quality required for the fish and plant growth.

Lettuce, herbs and specialty greens are well adapted to aquaponic culture systems and have very low to medium nutritional requirements (Diver, 2006). Hence in the present study, basil plant was selected for the study. At the time of harvest, basil plant growth in terms of mean height $(\mathrm{cm})$, height gain $(\%)$ and mean leaves yield (nos. plant ${ }^{-1}$ ) in all treatments including control varied significantly showing the highest mean height $(\mathrm{cm})$, height gain $(\%)$ and mean leaves yield (nos. plant ${ }^{-1}$ ) of basil plant in T3 followed by T2, T1 and lowest in control group (Table 3). In the present study, the highest

Table 2. Growth parameters of goldfish reared in media bed aquaponic system after a period of 36 days (Mean \pm SE)

\begin{tabular}{llll}
\hline Parameters & $\mathrm{T} 1$ & $\mathrm{~T} 2$ & $\mathrm{~T} 3$ \\
\hline Initial weight (g) & $3.32 \pm 0.45^{\mathrm{a}}$ & $3.32 \pm 0.45^{\mathrm{a}}$ & $3.32 \pm 0.45^{\mathrm{a}}$ \\
Final weight (g) & $8.7 \pm 0.08^{\mathrm{a}}$ & $8.94 \pm 0.06^{\mathrm{b}}$ & $9.18 \pm 0.12^{\mathrm{b}}$ \\
Weight gain (\%) & $162.05 \pm 2.09^{\mathrm{a}}$ & $169.3 \pm 1.59^{\mathrm{b}}$ & $176.5 \pm 2.08^{\mathrm{c}}$ \\
Initial length (cm) & $4.20 \pm 0.39^{\mathrm{a}}$ & $4.20 \pm 0.39^{\mathrm{a}}$ & $4.20 \pm 0.39^{\mathrm{a}}$ \\
Final length (cm) & $7.14 \pm 0.09^{\mathrm{a}}$ & $7.37 \pm 0.10^{\mathrm{a}}$ & $7.70 \pm 0.09^{\mathrm{b}}$ \\
Length gain (\%) & $70.0 \pm 2.18^{\mathrm{a}}$ & $75.6 \pm 2.39^{\mathrm{b}}$ & $83.3 \pm 2.18^{\mathrm{c}}$ \\
Specific growth rate (SGR) & $3.21 \pm 0.3^{\mathrm{a}}$ & $3.30 \pm 0.2^{\mathrm{b}}$ & $3.39 \pm 0.4^{\mathrm{c}}$ \\
Feed conversion ratio (FCR) & $1.196 \pm 0.12^{\mathrm{a}}$ & $1.193 \pm 0.12^{\mathrm{a}}$ & $1.190 \pm 0.10^{\mathrm{a}}$ \\
Protein efficiency ratio (PER) & $1.50 \pm 0.32^{\mathrm{a}}$ & $98.25 \pm 0.21^{\mathrm{a}}$ & $1.56 \pm 0.25^{\mathrm{a}}$ \\
Survival rate (\%) & $98.67 \pm 0.32^{\mathrm{a}}$ & & $98.23 \pm 0.23^{\mathrm{a}}$
\end{tabular}

Values bearing same superscripts do not differ significantly $(\mathrm{p}>0.05)$ 
Table 3. Growth parameters of basil plant reared in media bed aquaponic system after a period of 36 days (Mean $\pm \mathrm{SE}$ )

\begin{tabular}{lllll}
\hline Parameters & \multicolumn{4}{c}{ Treatments } \\
\cline { 2 - 5 } & $\mathrm{C}$ & $\mathrm{T} 1$ & $\mathrm{~T} 2$ & $\mathrm{~T} 3$ \\
\hline Initial height $(\mathrm{cm})$ & $4.2 \pm 0.3^{\mathrm{a}}$ & $4.2 \pm 0.3^{\mathrm{a}}$ & $4.2 \pm 0.3^{\mathrm{a}}$ & $4.2 \pm 0.3^{\mathrm{a}}$ \\
Final height $(\mathrm{cm})$ & $15.3 \pm 0.08^{\mathrm{a}}$ & $23.5 \pm 0.22^{\mathrm{b}}$ & $28.5 \pm 0.27^{\mathrm{c}}$ & $33.3 \pm 0.31^{\mathrm{d}}$ \\
Height gain (\%) & $256.35 \pm 9.9^{\mathrm{a}}$ & $471.43 \pm 6.87^{\mathrm{b}}$ & $560.32 \pm 9.15^{\mathrm{c}}$ & $704.76 \pm 11.25^{\mathrm{d}}$ \\
Leaves yield ( nos. plant $\left.^{-1}\right)$ & $37.93 \pm 1.79^{\mathrm{a}}$ & $54.3333 \pm 3.25^{\mathrm{b}}$ & $67.2667 \pm 1.13^{\mathrm{c}}$ & $81.60 \pm 0.80^{\mathrm{d}}$ \\
\hline
\end{tabular}

Values bearing same superscripts do not differ significantly $(p>0.05)$

growth of basil plant was observed in highest fish density over the culture period and this may be because of the availability of more fish waste and nutrients accumulated in the system for plants. Similarly, Delaide et al. (2016) also reported that interaction between microorganisms and dissolved organic matter present in the recirculating aquaculture system stimulates both root and shoot of the plant resulting in good plant crop.

In the present study, higher growth (both goldfish and basil) observed in higher density was mainly due to the better efficiency of plants to utilise nutrients and goldfish waste accumulated in the culture system resulting in maintenance of optimum water quality required for the fish and plant growth. Thus, this study concluded that stocking density of $700 \mathrm{~m}^{-3}$ for goldfish and 10 plants per $0.44 \mathrm{~m}^{2}$ for basil plants is optimum for maintaining good water quality and for obtaining highest production in media bed aquaponics.

\section{Acknowledgements}

We are extremely thankful to the Director, ICAR-CIFE, Mumbai and to the Director, ICAR-CIFA, Bhubaneswar, Odisha for providing the essential amenities and support to carry out the research work.

\section{References}

Ahmad, I., Babitha Rani, A. M., Verma, A. K. and Mudasir Maqsood, 2017. Biofloc technology: An emerging avenue in aquatic animal healthcare and nutrition. Aquac. Int., 25(3): 1215-1226.

Ahmad, I., Verma, A. K., Babitha Rani, A. M., Rathore, G., Saharan, N. and Hussain Gora, A. 2016. Growth, non-specific immunity and disease resistance of Labeo rohita against Aeromonas hydrophila in biofloc systems using different carbon sources. Aquaculture, 457: 61-67. https://doi.org/10.1016/j.aquaculture.2016.02.011

APHA 2005. Standards methods for the examination of water and waste water, $21^{\text {st }}$ edn. American Public Health Association, Washington, D.C., USA.

Boyd, C. E. and Lichtkoppler, F. 1979. Water quality management in fish ponds. Research and development series No. 22, International Centre for Aquaculture (J.C.A.A) Experimental Station, Auburn University, Alabama, p. 45-47.
Delaide, B., Goddek, S., Gott, J., Soyeurt, H. and Jijakli, M. H. 2016. Lettuce (Lactuca sativa L. var. sucrine) growth performance in complemented aquaponic solution outperforms hydroponics. Water, 8(10): 467; doi:10.3390/ w8100467.

Diver, S. 2006. Aquaponics - integration of hydroponics with aquaculture. Publication no. IP163. ATTRA, National Sustainable Agriculture Information Service, $25 \mathrm{pp}$.

FAO 2014a. The state of world fisheries and aquaculture: opportunities and challenges. Food and Agriculture Organisation of the United Nations, Rome, Italy, 243 pp.

FAO 2014b. Small scale aquaponic food production: integrated fish and plant farming, Technical Paper No. 589, FAO Fisheries and Aquaculture Department Rome, Italy, 288 pp.

Fedoroff, N. V., Battisti, D. S., Beachy, R. N., Cooper, P. J. M., Fischhoff, D. A., Hodges, C. N., Knauf, V. C., Lobell, D., Mazur, B. J., Molden, D., Reynolds, M. P., Ronald, P. C., Rosegrant, M. W., Sanchez, P. A., Vonshak, A. and Zhu, J. K. 2010. Radically rethinking agriculture for the $21^{\text {st }}$ century. Science, 327: 833-834. doi: 10.1126/science.1186834.

Hamlin, H. J. 2006. Nitrate toxicity in Siberian sturgeon (Acipenser baeri). Aquaculture, 253(1-4): 688-693. doi. org/10.1016/j.aquaculture.2005.08.025.

Haridas Harsha, A. K., Verma, G., Rathore Chandra Prakash, Paromita Banerjee, A. M., Babitha Rani and Irshad Ahmad, H. 2017. Enhanced growth and immunophysiological response of genetically improved farmed tilapia in indoor biofloc units at different stocking densities. Aquac. Res., 48(8): 4346-4355.

Hu, Z., Lee, J. W., Chandran, K., Kim, S., Brotto, A. C. and Khanal, S. K. 2015. Effect of plant species on nitrogen recovery in aquaponics. Bioresour. Technol., 188: 92-98. doi.org/10.1016/j.biortech.2015.01.013.

Hussain, T., Verma, A. K., Tiwari, V. K., Prakash, C., Rathore, G., Shete, A. P. and Saharan, N. 2015. Effect of water flow rates on growth of Cyprinus carpio var. koi (Cyprinus carpio L., 1758) and spinach plant in aquaponic system. Aquac. Int., 23: 369-384.

Jha, P. and Barat, S. 2005. The effect of stocking density on growth, survival rate and number of marketable fish produced of koi carps, Cyprinus carpio var. koi in concrete tanks. J. Appl. Aquac., 17(3): 89-102. doi.org/10.1300/ J028v17n03 07. 
Lorena, S., Cristea, V. and Oprea, L. 2008. Nutrients dynamic in an aquaponic recirculating system for sturgeon and lettuce (Lactuca sativa) production. Zootehnie si Biotehnologii, 41(2): 137-143.

Masser, M. P., Rackoy, J. and Losordo, T. M. 1999. Recirculating aquaculture tank production systems: management of recirculating systems. SRAC Publication no. 452, Southern Region Aquaculture Center, Missippie State University, Stoneville, $12 \mathrm{pp}$.

Nuwansi, K. K. T., Verma, A. K., Prakash, C., Tiwari, V. K., Chandrakant, M. H., Shete, A. P. and Prabhath, G. P. W. A. 2016. Effect of water flow rate on polyculture of koi carp (Cyprinus carpio var. koi) and goldfish (Carassius auratus) with water spinach (Ipomoea aquatica) in recirculating aquaponic system. Aquac. Int., 24(1): 385-393.DOI:10.1007/s10499-015-9932-5.

Nuwansi, K. K. T., Verma, A. K., Tiwari, V. K., Prakash, C. and Chandrakant, M. H. 2017. Standardisation of the stocking density ratios of koi carp (Cyprinus carpio var. koi): goldfish (Carassius auratus) in polyculture aquaponic recirculating system. Turkish J. Fish. Aquat. Sci., 17: 1271-1278

Rakocy, J. E. 1997. Integrating tilapia culture with vegetable hydroponics in recirculating systems. In: Costa-Pierce, B. A. and Rakocy, J. E. (Eds.), Tilapia aquaculture in Americas, World Aquaculture Society, Baton Rouge, Louisiana, United States, p. 163-184.

Rakocy, J. E., Masser, M. P. and Losordo, T. M. 2006. Recirculating aquaculture tank production systems: Aquaponics-integrating fish and plant culture. SRAC Publication no. 454, Southern Region Aquaculture Center, Missippie State University, Stoneville, 16 pp.
Rijn, J. V. 1995. The potential for integrated biological treatment systems in recirculating fish culture- A review. Aquaculture, 139: 181-201. DOI: 10.1016/0044-8486(95)01151-X.

Shete, A. P., Verma, A. K., Chadha, N. K., Prakash, C. and Chandrakant, M. H. 2015. A comparative study on fish to plant component ratio in recirculating aquaponic system with common carp and mint. J. Environ. Biol. Sci., 29(2): 323-329.

Shete, A. P., Verma, A. K., Chadha, N. K., Prakash, C. and Nuwansi, K. K. T. 2017. Evaluation of hydroponic subsystem for the culture of common carp, Cyprinus carpio and mint, Mentha arvensis in an aquaponic system. Aquac. Int., 25(3): 1291-1301.

Shete, A. P., Verma, A. K., Kohli, M. P. S., Dash, P. and Tandel, R. S. 2013a. Optimisation of stocking density for goldfish, Carassius auratus (Linnaeus, 1758) under aquaponic system. Isr. J. Aquac., 65: 1-6.

Shete, A. P., Verma, A. K., Tandel, R. S., Prakash, C., Tiwari, V. K. and Hussain. T. 2013b. Optimisation of water circulation period for the culture of goldfish with spinach in aquaponic system. J. Agric. Sci., 5(4): 26-30. DOI: $10.5539 /$ jas.v5n4p26.

Turcios, A. E. and Papenbrock. J. 2014. Sustainable treatment of aquaculture effluents - what can we learn from the past for the future? Sustainability, 6: 836-856. doi.org/10.3390/ su6020836

Zarski, D., Kucharczyk, D., Targonska, K., Krejszeff, S., Czarkowski, T., Babiarz, E. and Nowosielska, D. B. 2010. Dynamics of nitrogen and phosphorus in closed and semi-closed recirculating aquaculture systems during the intensive culture of goldfish, Carassius auratus (L.) fry. Arch. Pol. Fish., 18: 187-193. DOI 10.2478/v10086-0100022-z. 